\title{
BIODIVERSITY SURVEY METHOD FOR DETECTING SPECIES OF CONSERVATION CONCERN IN NOVA SCOTIA PROTECTED WILDERNESS AREAS AND NATURE RESERVES
}

\author{
ROBERT P. CAMERON* \\ Nova Scotia Department of Environment, \\ Halifax, Nova Scotia, Canada BON $2 \mathrm{HO}$
}

\begin{abstract}
Biodiversity transect surveys have been undertaken in protected Wilderness Areas and Nature Reserves in Nova Scotia, Canada since 2002. They document plant communities as well as plant and animal species of conservation concern. The Protected Areas Branch wished to have an assessment of the value of these surveys. Fourteen years of sampling data in 80 Wilderness Areas and Nature Reserves were used to determine detectability, density and distribution of species of conservation concern. Two hundred and twenty-two occurrences of species of interest were recorded. Nine bird species and 19 plant and lichen species were recorded 2 or more times. Densities for bird species ranged from 0.023 individuals per $\mathrm{km}$ of transect $( \pm 0.012)$ for the Boreal Chickadee to 0.727-km $( \pm 0.007)$ for the Eastern Wood Pewee. Plants densities ranged from 0.02 individuals per $\mathrm{km}( \pm 0.01)$ for the Round-Leaved Orchid to 27.1 individuals per $\mathrm{km}$ $( \pm 10.4)$ for the Bulblet Bladder Fern. Most of the species of conservation concern were rare with $66 \%$ being found only once. The method used for the current biodiversity transect surveys appears to be adequate for the more common species of conservation concern when a single protected area is examined. However, less than half the species analyzed had a $95 \%$ confidence of being detected within the mean sample length of the transect $(4.5 \mathrm{~km})$. All species analyzed were within the sample length when all protected areas were combined suggesting that the present methodology is more useful as a system wide survey rather than for individual protected areas. Twenty-eight of eighty-three species of conservation concern detected during the survey occurred frequently enough for density calculations. Methods that might increase the value of the surveys include grouping species, using species richness measures, using occupancy or accepting lower confidence intervals and confidence limits.

Keywords: biodiversity survey, species of conservation concern, species at risk, protected areas
\end{abstract}

Author to whom correspondence should be addressed:

robert.cameron@novascotia.ca 


\section{INTRODUCTION}

The primary purpose of Wilderness Areas and Nature Reserves in Nova Scotia is the protection of biodiversity (Wilderness Areas Protection Act 1998, Special Places Act 1989). In some cases, this means protection of areas or habitats for species of conservation concern such as the Atlantic Coastal Plain Flora or Canada Lynx. The areas or reserves also protect rare or at risk ecosystems, e.g. old growth forest or rich floodplain forest (Cameron 2004). In both cases, specialized surveys are required to document the characteristics of the biodiversity which the area was intended to protect.

The largest area of Wilderness Areas and Nature Reserves, were established to protect biodiversity as a whole, including species, ecosystems and ecological processes. The protected areas program achieves this type of biodiversity protection through the protection of representative ecosystems in Natural Landscapes. The premise is that if a variety of ecosystems are captured, most of the biodiversity will be preserved (Cameron \& Williams 2011).

Ecosystems that form the Natural Landscapes in Nova Scotia have been mapped using a Geographical Information System (GIS) that includes remotely sensed data (Cameron \& Williams 2011). These data provide a low-resolution surrogate assessment of spatial distribution of biodiversity. To ensure that the remotely sensed data are capturing the predicted range of biodiversity, field surveys of all newly proposed protected areas are undertaken. The surveys were designed to be rapid, repeatable and scientifically rigorous. ${ }^{1}$ The advantages of a basic field inventory are that it gives planners an indication that what is being proposed for protection actually occurs on the ground. It also serves as a check on the predictability of the remotely derived GIS data as well as a benchmark for measuring impacts such as climate change. It can also be a resource for planning recreational developments.

It is impractical to measure all biodiversity in a field survey and therefore the Protected Areas Branch chose to use plants and plant communities as surrogates to assess overall biodiversity. Transects which bisect the variety of mapped ecosystems are traversed and vegetation plots established to measure plant community composition and structure. In addition, any animal species of conservation

Authorities for species are provided in the text only when they are not included in Appendix 1. 
interest, heard or seen and any plant species of conservation concern seen while traversing the transects were also recorded. The primary purpose of recording such species is so that planners were aware of their presence when planning for developments. In addition, ecologists have a list of the species within surveyed protected areas. Since the transects are a stratified systematic sampling, they are statistically valid. The Protected Areas Branch wanted to know how well this sampling methodology captures species of conservation concern and whether this method could be used to calculate population density estimates with reasonable confidence intervals (CI).

\section{METHODS}

\section{Field Sampling}

Methods for plot selection were designed using the Ecological Society of America Guidelines "Describing Associations and Alliances of the U.S. National Vegetation Classification" (Jennings et al. 2004). Topographic features and dominant plant communities were identified in the area to be surveyed using Nova Scotia Environment GIS Ecosystem Classification (Cameron \& Williams 2011). Transects were placed within each area such that it traversed the variety of topographical features and dominant plant communities of each landscape. The mean transect length was $4.5 \mathrm{~km}$ and it was navigated once. Plots measuring $20 \mathrm{~m}$ x $20 \mathrm{~m}$ were established along or near transects in areas that represented a relatively homogenous vegetation community. New plots were set out each time a different vegetation community was encountered. The presence and cover class of each plant species at 5 vertical layers (canopy, sub-canopy, shrub, herb, moss-lichen) was recorded in each plot following standards set out by the Ecological Society of America (Jennings et al. 2004).

Any plant species of conservation concern within $3 \mathrm{~m}$ of either side of the transect were recorded with a GPS location. Songs or calls heard and sightings of bird species of conservation concern were also recorded. The species of conservation concern that were recorded on transects were those listed by COSEWIC as endangered, threatened or of Special Concern as part of the federal Species at Risk Act, and those listed under the provincial Endangered Species Act as endangered, threatened or vulnerable. Furthermore, any species that is listed as S1, S2 or S3 by the Atlantic Canada Conservation Data Centre 
were recorded. This inventory did not include sightings of species of conservation concern seen while walking to or from the transect. The inventory also did not use information from specialized surveys undertaken by staff to examine, for example the Atlantic coastal plain flora or cyanolichens. Nomenclature for plants follows Brouillet et al. (2017). Nomenclature for birds follows American Ornithological Society Checklist latest supplement (Chesser et al. 2017).

\section{Statistical Analysis}

Fourteen years of transect data were used to determine the sample sizes needed for a $5 \%$ chance of type 2 error and $95 \%$ confidence intervals for density measures.

Green and Young (1993) suggested sample size given a chosen level of type 2 error can be calculated using the following:

$$
\mathrm{N}=-(1 / \mathrm{D}) \log \beta
$$

Where $\mathrm{N}$ is sample size, $\mathrm{D}$ is the known density and $\beta$ is the type 2 error. This equation assumes a Poisson distribution. Green and Young (1993) concluded from their study that for most situations a Poisson distribution would be adequate and even if the species are not randomly distributed the Poisson distribution will be adequate if the mean density is very low and the spatial distribution is not highly aggregated. This equation is adequate for quadrat sampling. If the assumption is that the transect is a series of connecting quadrats (Stehman \& Salzer 2000), equation (1) can be adopted for this purpose. A maximum type 2 error of 0.05 was used.

Density D can be calculated as (Buckland et al. 1993):

$$
\mathrm{D}=\mathrm{Y} / \mathrm{A}=\sum_{\mathrm{u}=1}^{\mathrm{N}} \mathrm{Y}_{\mathrm{u}} / \sum^{\mathrm{N}}{ }_{\mathrm{u}=1} \mathrm{a}_{\mathrm{u}}
$$

Where $\mathrm{Y}=$ total number of objects in the population and $\mathrm{A}$ is the total area of study; $Y_{u}$ is the number of objects in the transect and $a_{u}$ is area of transect $u . \sum_{u=1} N$ is the summation over all transects $N$.

Standard error can be calculated by first calculating the variance, denoted V'(D') (Thompson 1992):

$$
\mathrm{V}^{\prime}\left(\mathrm{D}^{\prime}\right)=1 / \overline{\mathrm{a}}^{2}(\mathrm{~N}-\mathrm{n} / \mathrm{N}) \mathrm{S}_{\mathrm{e}}^{2} / \mathrm{n}
$$

Where $\mathrm{S}_{\mathrm{e}}^{2}=\sum_{\mathrm{s}}\left(\mathrm{y}_{\mathrm{u}}-\mathrm{D}^{\prime} \mathrm{a}_{\mathrm{u}}\right)^{2} /(\mathrm{n}-1)$. The standard error is the square root of the variance V'(D') (Buckland et al. 1993). 
Buckland et al.(1993) provided the equation for calculating sample size for transect sampling given a specified confidence level:

$$
\mathrm{L}=\left(\mathrm{b} /\left(\mathrm{cv}_{\mathrm{t}}\left(\mathrm{D}^{\prime}\right)^{2}\right)\left(\mathrm{L}_{0} / \mathrm{n}_{0}\right)\right.
$$

Where $\mathrm{L}$ is transect length, $\mathrm{cv}_{\mathrm{t}}\left(\mathrm{D}^{\prime}\right)$ is the coefficient of variation for given density D', $L_{0}$ is the length of the survey transect and $n_{0}$ is the number of objects detected. The variable $b$ can be estimated as $b^{\prime}=\mathrm{n}_{0}\left(\mathrm{cv}_{\mathrm{t}}\left(\mathrm{D}^{\prime}\right)^{2}\right.$ (Burnham et al. 1980). A coefficient of variation of 0.10 was used in this analysis.

To determine if species were distributed randomly across the transects, a chi-square test goodness of fit of a Poisson distribution was used for all birds combined and all plants combined and for each species individually. The Chi square test using a Poisson distribution is suitable for samples with a small mean (ideally around 1) (Zar 1996). Zar (1996, page 575) also indicated that if a population has random distribution then $\sigma^{2}=\mu$ and $\sigma^{2} / \mu=1$. In a uniformly distributed population $\sigma^{2} / \mu<1$ and clustered population $\sigma^{2} / \mu>1$.

For plants that occurred in large numbers ( $>100$ stems), local populations were estimated. Mosses and lichens were enumerated by number of colonies. For calculation of densities, transects were stratified for each species to capture broad categories of suitable habitat. For example, only aquatic transects were used for Common Loon analysis, transects that traversed mature deciduous and mixed wood were used for Eastern Wood Pewee and only transects within Windsor Geological Group were used for Yellow Lady's Slipper.

\section{RESULTS}

Between 2002 and 2016, $361 \mathrm{~km}$ of transect in 80 existing and proposed Wilderness Areas and Nature Reserve were traversed and occurrences of species of conservation concern were recorded. The mean transect length for protected area was $4.51 \mathrm{~km}$. Two hundred and twenty-two occurrences of species of conservation concern were recorded during the transects. Fifty-nine species of plants and lichens (Table 1) and twenty-five species of vertebrates (Table 2) were observed. Species of conservation concern occurred at a density of one per $614 \mathrm{~m}$.

The results showed that species were not distributed randomly across transects for all plants combined $(\mathrm{P}<0.001)$ or for all birds 
Table 1 Plant and lichen species of conservation of concern tallied within 80 protected area on transects between 2004 and 2016.

\begin{tabular}{|c|c|c|}
\hline Scientific Name & Common Name & $\begin{array}{c}\text { Number of Times } \\
\text { Encountered }\end{array}$ \\
\hline
\end{tabular}

Anemone quinquefolia

Asplenium trichomanes

Asplenium trichomanes-ramosum

Atrichum crispum

Atrichum undulatum

Betula michauxii

Buxbaumia aphylla

Caltha palustris

Carex swanii

Caulophyllum thalictroides

Cladina stygia

Collema nigrescens

Cornus suecica

Cypripedium parviflorum

Cystopteris bulbifera

Degelia plumbea

Dryopteris fragrans

Empetrum eamesii

Equisetum hyemale

Equisetum scirpoides

Equisetum variegatum

Erigeron hyssopifolius

Fuscopannaria leucosticta

Fraxinus nigra

Galium kamtschaticum

Goodyera oblongifolia

Goodyera repens

Goodyera tesselata

Hudsonia ericoides

Lachnanthes caroliniana

Lilium canadense

Listera australis

Minuartia groenlandica

Packera paupercula

Panax trifolius

Platanthera macrophylla

Platanthera orbiculate

Polygonum scandens

Polystichum braunii

Rhamnus alnifolia

Rhodobryum ontariense

Sanguinaria canadensis

Schizaea pusilla

Sclerophora peronella

Shepherdia canadensis

Smilax rotundifolia (Atlantic pop.)

Solidago multiradiata

$\begin{array}{ll}\text { Wood Anemone } & 1 \\ \text { Maidenhair Spleenwort } & 1 \\ \text { Green Spleenwort } & 1 \\ \text { Atrichum Moss } & 1 \\ \text { Common Smooth-Cap Moss } & 2 \\ \text { Michaux's Dwarf Birch } & 4 \\ \text { Brown Shield Moss } & 1 \\ \text { Yellow Marsh Marigold } & 1 \\ \text { Swan's Sedge } & 1 \\ \text { Blue Cohosh } & 2 \\ \text { Black-footed Reindeer Lichen } & 2 \\ \text { Blistered Tarpaper Lichen } & 1 \\ \text { Swedish Bunchberry } & 1 \\ \text { Yellow Lady's-Slipper } & 8 \\ \text { Bulblet Bladder Fern } & 8 \\ \text { Blue Felt Lichen } & 1 \\ \text { Fragrant Wood Fern } & 1 \\ \text { Pink Crowberry } & 1 \\ \text { Common Scouring-Rush } & 1 \\ \text { Dwarf Scouring-Rush } & 2 \\ \text { Variegated Horsetail } & 1 \\ \text { Hyssop-leaved Fleabane } & 2 \\ \text { White-Rimmed Shingle Lichen } & 1 \\ \text { Black Ash } & 5 \\ \text { Northern Wild Licorice } & 1 \\ \text { Menzies' Rattlesnake-Plantain } & 1 \\ \text { Lesser Rattlesnake-Plantain } & 3 \\ \text { Checkered Rattlesnake-Plantain } & 5 \\ \text { Pinebarren Golden Heather } & 1 \\ \text { Redroot } & 1 \\ \text { Canada Lily } & 3 \\ \text { Southern Twayblade } & 1 \\ \text { Greenland Stitchwort } & 1 \\ \text { Balsam Groundsel } & 1 \\ \text { Dwarf Ginseng } & 1 \\ \text { Large Round-Leaved Orchid } & 1 \\ \text { Small Round-Leaved Orchid } & 3 \\ \text { Climbing False Buckwheat } & 1 \\ \text { Braun's Holly Fern } & 1 \\ \text { Alder-leaved Buckthorn } & 1 \\ \text { Ontario Rose Moss } & 1 \\ \text { Bloodroot } & 1 \\ \text { Little Curlygrass Fern } & 1 \\ \text { Frosted Glass-Whiskers } & 1 \\ \text { Soapberry } & \\ \text { Round-leaved Greenbrier } & \\ \text { Multi-rayed Goldenrod } & \\ \end{array}$

Table 1 cont'd 
Table 1 Cont'd

\begin{tabular}{llc}
\hline Scientific Name & Common Name & $\begin{array}{c}\text { Number of Times } \\
\text { Encountered }\end{array}$ \\
\hline Solorina saccata & Gypsum Lichen & 1 \\
Sphagnum quinquefarium & Five-ranked Peat Moss & 1 \\
Sphagnum torreyanum & Torrey's Peatmoss & 1 \\
Sphagnum wulfianum & Wulf's Peat Moss & 9 \\
Sticta fuliginosa & Peppered Moon Lichen & 1 \\
Tiarella cordifolia & Heart-leaved Foamflower & 1 \\
Timmia megapolitana & Metropolitan Timmia Moss & 1 \\
Triosteum aurantiacum & Orange-fruited Tinker's Weed & 1 \\
Vaccinium boreale & Northern Blueberry & 1 \\
Vaccinium uliginosum & Alpine Bilberry & 3 \\
Viola labradorica & Labrador Violet & 1 \\
Woodwardia areolate & Netted Chain Fern & 1 \\
\hline
\end{tabular}

Table 2 Vertebrate species of conservation concern tallied within 80 protected area on transects between 2004 and 2016.

\begin{tabular}{llc}
\hline Scientific Name & Common Name & $\begin{array}{c}\text { Number of Times } \\
\text { Encountered }\end{array}$ \\
\hline Accipiter gentilis & Northern Goshawk (B) & 3 \\
Actitis macularius & Spotted Sandpiper (B) & 1 \\
Alca torda & Razorbill (B) & 1 \\
Alces americanus & Mainland Moose (M) & 1 \\
Calidris pusilla & Semipalmated Sandpiper (B) & 1 \\
Charadrius vociferus & Killdeer (B) & 1 \\
Chelydra serpentina & Snapping Turtle (R) & 1 \\
Chordeiles minor & Common Nighthawk (B) & 5 \\
Contopus cooperi & Olive-sided Flycatcher (B) & 11 \\
Contopus virens & Eastern Wood-Pewee (B) & 14 \\
Empidonax flaviventris & Yellow-bellied Flycatcher (B) & 3 \\
Gavia immer & Common Loon (B) & 8 \\
Glyptemys insculpta & Wood Turtle (R) & 1 \\
Hirundo rustica & Barn Swallow (B) & 1 \\
Passerculus sandwichensis & Savanah Sparrow (B) & 1 \\
Perisoreus canadensis & Gray Jay (B) & 2 \\
Petrochelidon pyrrhonota & Cliff Swallow (B) & 1 \\
Phalacrocorax carbo & Great Cormorant (B) & 1 \\
Picoides arcticus & Black-backed Woodpecker (B) & 1 \\
Poecile hudsonica & Boreal Chickadee (B) & 2 \\
Sterna hirundo & Common Tern (B) & 1 \\
Thamnophis sauritus & Eastern Ribbonsnake (R) & 1 \\
Tringa semipalmata & Willet (B) & 1 \\
Wilsonia canadensis & Canada Warbler (B) & 4 \\
\hline
\end{tabular}

combined $(\mathrm{P}<0.001)$. None of the tests for individual species indicated random distribution $(\mathrm{P}<0.05)$. Plant distribution for all plants combined may be clustered because $\sigma 2 / \mu$ is much greater than one (205.167). However, $\sigma 2 / \mu$ for Bloodroot (0.85) and Wulf's Moss 
(0.89) were less than one suggesting that these species have a more uniform distribution. All other plants species had $\sigma 2 / \mu$ greater than one suggesting they each have a clustered distribution. Bird species distribution for all birds combined may be more uniform because $\sigma 2 / \mu=0.730$. However, for most bird species individually, $\sigma 2 / \mu$ was greater than one, suggesting clustered distributions. Only Common Loon (0.62) and Gray Jay (0.85) had $\sigma 2 / \mu$ less than one.

Nine bird species and 19 plant and lichen species were recorded 2 or more times (Table 3). Densities for bird species ranged from

Table 3 Density of vertebrates, plants and lichens tallied two or more times in transects including confidence intervals (Standard Error), sample size required to be $95 \%$ confident of detecting a species and sample size required to sample a population with a confidence interval of 0.1 or $10 \%$.

\begin{tabular}{|c|c|c|c|}
\hline $\begin{array}{l}\text { Species } \\
\text { (number }\end{array}$ & $\begin{array}{c}\text { Density } \\
\text { to be } 95 \% \\
\text { per } \mathbf{k m} \text { ) }\end{array}$ & $\begin{array}{l}\text { Sample size } \\
\text { required to } \\
\text { confident of } \\
\text { detecting a } \\
\text { species }(\mathrm{km})\end{array}$ & $\begin{array}{c}\text { Sample size required } \\
\text { to sample a } \\
\text { population with a } \\
\text { confidence interval } \\
\text { of } 0.1 \text { or } 10 \%(\mathrm{~km})\end{array}$ \\
\hline Alpine Bilberry & $2.37 \pm 6.40$ & 0.5 & 52.7 \\
\hline Black Ash & $0.22 \pm 0.03$ & 6.0 & 46.4 \\
\hline \multicolumn{4}{|l|}{ Black-Footed Reindeer } \\
\hline Lichen & $0.18 \pm 0.02$ & 6.9 & 16.0 \\
\hline Bloodroot & $0.10 \pm 0.01$ & 13.5 & 62.3 \\
\hline Blue Cohosh & $5.36 \pm 0.13$ & 0.2 & 3.4 \\
\hline Boreal Chickadee & $0.02 \pm 0.01$ & 55.7 & 171.3 \\
\hline Bulbet Bladder Fern & $27.10 \pm 10.40$ & 0.1 & 45.2 \\
\hline Canada Lily & $0.13 \pm 0.04$ & 10.1 & 62.3 \\
\hline Canada Warbler & $0.30 \pm 0.03$ & 4.3 & 26.7 \\
\hline \multicolumn{4}{|l|}{ Checkered Rattlesnake } \\
\hline Plantain & $0.04 \pm 0.01$ & 35.5 & 163.8 \\
\hline Common Loon & $0.10 \pm 0.12$ & 13.5 & 83.2 \\
\hline Common Nighthawk & $0.04 \pm 0.03$ & 32.0 & 197.1 \\
\hline Common Smooth-Cap Moss & $3.32 \pm 1.52$ & 0.3 & 60.3 \\
\hline Dwarf Ginseng & $0.32 \pm 0.20$ & 4.2 & 93.8 \\
\hline Dwarf Scouring-Rush & $1.00 \pm 0.54$ & 1.0 & 45.2 \\
\hline Eastern Wood Pewee & $0.73 \pm 0.01$ & 1.8 & 44.0 \\
\hline Frosted Glass Whiskers & $3.02 \pm 0.04$ & 0.4 & 15.9 \\
\hline Gray Jay & $0.04 \pm 0.01$ & 37.1 & 171.3 \\
\hline Hyssop's Fleabane & $0.42 \pm 0.21$ & 3.1 & 45.2 \\
\hline Lesser Rattlesnake Plantain & $0.09 \pm 0.06$ & 14.8 & 171.3 \\
\hline Michaux’s Dwarf Birch & $3.32 \pm 9.80$ & 0.4 & 52.7 \\
\hline Northern Goshawk & $0.24 \pm 0.01$ & 5.5 & 25.4 \\
\hline Olive-Sided Flycatcher & $0.19 \pm 0.06$ & 7.3 & 134.3 \\
\hline Small Round-Leaved Orchid & $0.02 \pm 0.01$ & 56.9 & 175.1 \\
\hline Soapberry & $3.32 \pm 1.66$ & 0.4 & 45.2 \\
\hline Wulf's Moss & $0.05 \pm 0.01$ & 25.6 & 177.6 \\
\hline Yellow Lady Slipper & $0.11 \pm 0.05$ & 11.7 & 45.2 \\
\hline Yellow-Bellied Flycatcher & $0.119 \pm 0.08$ & 10.9 & 50.3 \\
\hline
\end{tabular}


0.023 individuals per $\mathrm{km}( \pm 0.012)$ for Boreal Chickadee to 0.727 individuals per $\mathrm{km}( \pm 0.007)$ for Eastern Wood Pewee. Plants densities ranged from 0.02 individuals per $\mathrm{km}( \pm 0.01)$ for Round-Leaved Orchid to 27.1 individuals per $\mathrm{km}( \pm 10.4)$ for Bulblet Bladder Fern. Vascular plants tended to have higher densities than other groups. More than $40 \%$ of vascular plant species in this study had densities greater than 1 , while no bird species had density more than 1 . Lichens and mosses each had only 2 species recorded; both with one species density greater than 3 (Common Smooth-Cap Moss, Frosted Glass Whiskers) and one species with density less than 1 (Wulf's Moss, Black-Footed Reindeer Lichen). The range of densities found in plants was much greater $(0.02-27.10)$ than for birds $(0.02-0.73)$.

\section{DISCUSSION}

Most of the species of conservation concern sampled in this study were rare. Indeed, $66 \%$ of species were found only once. For most ecological communities, a few species are common but the greater majority are rare (MacArthur \& Wilson 1967, Gaston 1994). Those species that are of greatest conservation concern are most often rare (Meffe \& Carroll 1997, Fagan et al. 2002, Hartley \& Kunin 2003). This may be, in part, because smaller populations are more susceptible to stochastic events (Cunningham \& Lindemayer 2005).

Density estimates from this study are comparable to many densities for the same species in other studies in Nova Scotia despite differing methodologies. COSEWIC (2008) report densities of Canada Warbler between 0.001 individuals per ha, to 0.250 individuals per ha in Nova Scotia. Estimates from this study are between this range at 0.005 individuals per ha. COSEWIC (2012) provided an estimate of 30,000 individuals of Eastern Wood Pewee for Nova Scotia and when divided by the total area of hardwood and mixed wood forest (preferred habitat) in the province (Nova Scotia Department of Natural Resources 2017) provide an overall provincial estimate of 0.0195 individuals per ha. The estimate from this study is only slightly less at 0.012 individuals per ha. Other density estimates for birds from this study are less similar to other studies. The estimate for YellowBellied Flycatcher (0.001 individuals per ha) is much lower than the 1.0 to 18.0 pairs per ha reported for Fundy National Park in New Brunswick (Freedman and Johnson 1999). However, the density 
estimate for Northern Goshawk (0.004 individuals per ha) is much higher than reported for Pennsylvania (0.00012 individuals per ha) and western North America (0.00107 individuals per ha) (Squires and Kennedy 2006).

Plants show much greater variation between studies. Oberndorfer and Lundholm (2008) found Northern Blueberry only once in their plots along $500 \mathrm{~m}$ transects in 6 coastal heathland sites. Northern Blueberry was also only found once in this study suggesting the rarity of this species. Oberndorfer and Lundholm (2008) also found 0.417 colonies per ha of Black-Footed Reindeer Lichen, which is much higher than the 0.003 colonies per hectare found in this study. Taylor and Tam (2012) report over 34 Orange-fruited Tinker's Weed stems per km of transect in their study sites in Nova Scotia, which was found only once in this study.

Although several other studies reported rare plant abundances in Nova Scotia, direct comparisons of abundance are not possible because of differences in methodology. Hill and Garbary (2011) measured abundances of four rare forest herbs also found in this study. Blue Cohosh, Bloodroot, Orange-fruited Tinker's Weed and Canada Lily were restricted to floodplain habitats and not found in adjacent upland forests in their study and this was the case for this study. Neily et al. (2011) likely has the most comprehensive assessment of plant abundances in their 1456 forest vegetation plots. They report Bloodroot in only 12 plots and while Blue Cohosh and Canada Lily are mentioned, they are not reported in their plot data. Neily et al. (2011) report Bulblet Bladder Fern from only 2 plots in their study. Yellow Lady's Slipper is mentioned but not reported in their plot data. Although direct comparison of abundances is not possible, these studies indicate the rarity of these plants within the landscape in Nova Scotia.

\section{Ability to Detect Species of Conservation Concern}

The rarity of species of conservation concern leaves ecologists with the challenge of designing statistically valid surveys that are able to detect small populations over large areas. The method described in the current study was designed to cover large areas and acquire data rapidly. However, it may only be an adequate sampling design for the more common species of concern when examining single protected areas alone. For example, only twelve of twenty-eight species 
analyzed ( 2 bird, 10 plant species) had a 95\% confidence of being detected within the mean survey length of a protected area $(4.5 \mathrm{~km})$.

If, however, the objective is to detect species of conservation concern within the protected areas network across the province, then the methodology may be more useful. The sample size required for $95 \%$ confidence of detecting all 28 analyzed species was well within the $361 \mathrm{~km}$ of total survey length. It is important to note that most species of conservation concern were only detected once using the approach described above. Sixty-three percent of vertebrates and sixty-eight percent of plants and lichens were only detected once. There are also likely to be species of conservation concern present in the protected areas that were not detected.

\title{
Distribution of Species
}

The clustered distribution of plants suggests that with the detection of one species of conservation concern, others will also be present in the same area. When this occurs, more focussed surveys may be warranted. Clustering of plant species often occurs because of particular habitat characteristics; for example, species that require calcareous soil are often found together (Zinck 1998). Similarly, many floodplain inhabiting plants such as Blue Cohosh, Canada Lily and Bloodroot are found together (Hill \& Garbary 2011).

The more even distribution of bird species of conservation concern may reflect the fact that many of the bird species detected are territorial songbirds. Therefore, they are more likely to be spread out, at least within suitable habitat. Sherry and Holmes (1985) found 4 of 7 songbirds had an even distribution in northern hardwood forests in New Hampshire. Some inferences can be made; for example, the Boreal Chickadee and Gray Jay can be useful indicators of species at the southern extent of their range and an important indicator of the rate of climate change.

\begin{abstract}
Ability to Determine Density
The ability to determine density (number of individuals per length of transect) can be helpful for protected areas managers. It can aid in long-term monitoring to determine outcomes of management intervention or the impact of human use. Population density can be used as a benchmark to compare against the working landscape and this can, in turn, help ecologists determine causes of population declines.
\end{abstract}


Only 28 of 83 species of conservation concern detected in surveys were recorded frequently enough for analysis. However, because plants appear to have a clustered distribution it may be possible to use some species as proxies for rarer species that have abundances too low for density calculations. For example, changes in populations of the four calcareous soil associated plant species, Bulblet Bladder Fern, Hyssop's Fleabane, Soapberry and Yellow Lady's Slipper, may reflect issues with the karst or limestone ecosystems. These species may predict the occurrence of rarer and endangered species such as the Ram's-Head Lady's Slipper that is sometimes found with them (Neily et al. 2011). Monitoring population levels of floodplain associated species such as Blue Cohosh, Canada Lily or Bloodroot, and may also provide information on changes within that community.

Both Alpine Bilberry and Michuax's Dwarf Birch had confidence intervals greater than actual densities. This was likely due to the high degree of variation in population counts between sites. Although arctic-alpine plants were found distributed in a clumped pattern, species were not often found together. Abundances could be very high in some areas and very low in others. Cameron and BondrupNielsen (2013) found a similar pattern in their study of heathlands in Nova Scotia.

\section{Suitability of Method for Sampling Species of Conservation Concern}

Although only some species of conservation concern were detected and have density determined by the data analysis, there may be different approaches or ways the data could be used. Nichols et al. (2000) suggested one approach for bird species is to group a priori different species with a similar predicted variation in detection probability (e.g. easy or difficult to detect). This approach can be tested a posteriori. In order for this approach to have some biological meaning, it may be necessary to additionally group species with similar population dynamics (MacKenzie et al. 2005) and habitat requirements.

The purpose of the survey needs to also be considered. For example, if one is interested in the effects of sugar maple decline on bird species it would be necessary to group species associated with sugar maple forests. Since one of the purposes of protected areas in Nova Scotia is to provide habitat for birds requiring large interior forest, this kind of grouping may be helpful. Another potentially useful grouping may be boreal forest birds. This grouping may lead 
to a better understanding of the effects of climate change in the hemi-boreal forests of Nova Scotia.

Another approach to using rare species data is to examine species richness (MacKenzie et al. 2005). This may be useful when examining community level questions and as a way to make use of data on rare species that might otherwise not lend itself to analysis. Because not all species are likely to be detected in a plot, estimates need to be calculated and a number of methods have been proposed (Bunge \& Fitzpatrick 1993). For territorial rare species, MacKenzie et al. (2005) suggested occupancy rather than abundance as an alternative measure. As with species richness, there is the problem of imperfect detectability. MacKenzie et al. (2005) provides examples to address imperfect detectability by repeated sampling during a single or several seasons. Probabilistic arguments are then applied to form a model likelihood that can be used to obtain parameter estimates. Forest birds monitored in this study may be a group to which this method could be usefully applied.

One approach not addressed by MacKenzie et al. (2005) in their review, is accepting larger confidence intervals for some species. Another consideration is making adjustments to acceptable levels of confidence or survey length which can yield improvements in detectability. For example, adjusting the confidence to $80 \%$ means 16 species are likely to be detected within the mean survey length instead of the current 12 species. If the average survey length was doubled the number of species likely to be detected with $95 \%$ confidence is 16 or 23 with $80 \%$ confidence. However, accepting these kinds of adjustments will make it more difficult to detect change and there will be less certainty comparing areas. The risk is that impacts will be well underway before a change is detected. This risk needs to be evaluated by species to determine if some other measure or intensive sampling is warranted.

\section{Protected Areas Ability to Capture Species of Conservation Concern}

Protected areas not designed to capture species of conservation concern may not be adequate for protecting vulnerable species. Only about $8 \%$ of the vascular plant species of conservation concern known to occur in the province, and about $7 \%$ of non-vascular flora, were captured in this study. Birds fared better with about $19 \%$ of species captured. Three of the four reptiles of conservation concern were 
found during the surveys and one of thirteen mammals. It should be noted that the protected areas assessed were not designed to protect specifically species of conservation concern, but rather to protect representative ecosystems. Other protected areas in the network are designed for species at risk (Cameron \& Williams 2011) such as the 23,000 ha of nature reserves versus the 496,000 ha of wilderness area primarily focused on ecosystem representation (Nova Scotia Department of Environment 2018). The results of this study support the need to have protected areas specifically for species of conservation concern because protected areas designed to capture representative ecosystems may not capture the rare species of conservation concern. There are also likely species of concern that occur in the study areas but were not captured by the survey.

\section{CONCLUSION}

The method described in this study is suitable for detecting and determining density for many species of conservation concern within the protected areas network in Nova Scotia. Modification of the analysis used in the present study, as suggested in the discussion, could yield useful results for individual protected areas or for some of the more rare species of conservation concern.

Acknowledgements The author would like to thank Leif Helmer, David MacKinnon, Sally Steele and David Williams for help in field data collection as well as the many students over the years. I would also like to thank the PNSIS Associate Editor, David Richardson, for helpful suggestions to the manuscript and to two anonymous reviewers.

\section{REFERENCES}

Brouillet,L.,Desmet,P.,Coursol,F., Meades,S.J.,Favreau,M., Anions, M., Bélisle, P., Gendreau, C., Shorthouse, D., \& contributors. (2017). Database of Vascular Plants of Canada (VASCAN). Online at http:// data.canadensys.net/vascan and http://www.gbif.org/dataset/3f8a12973259-4700-91fc-acc4170b27ce, released on 2010-12-10. GBIF key: 3f8a1297-3259-4700-91fc-acc4170b27ce. Data paper ID: doi: http://doi. org/10.3897/phytokeys.25.3100 [accessed January 2018].

Buckland, S.T., Anderson, D.R., Burnham, K.P., \& Laake, J.L. (1993).

Distance Sampling Estimating Abundance of Biological Populations. Chapman and Hall, London. 
Bunge, J., \& Fitzpatrick, M. (1993). Estimating the number of species: a review. Journal of the American Statistical Association 88: 364-373.

Burnham, K. P., Anderson, D.R., \& Laake, J.L. (1980). Estimation of density from line transect sampling of biological populations. Wildlife Monographs 72: 1-202.

Cameron, R.P. (2004). Resource Guide and Ecological Atlas for Conducting Research in Nova Scotia's Wilderness Areas and Nature Reserves. Protected Areas Branch, Nova Scotia Environment and Labour Technical Report 0401, Halifax, NS.

Cameron, R.P., \& Bondrup-Nielsen,S. (2013). Plant communities within Atlantic coastal heathlands in Nova Scotia. Northeastern Naturalist 20: 694-709.

Cameron, R.P., \& Williams, D. (2011). Completing an ecosystem classification system for Nova Scotia. Natural Areas Journal 31: 92-96.

Chesser, T.R., Burns, K.J., Cicero, C., Dunn, J.L., Kratter, A.W., Lovette, I.J., Rasmussen, P.C., Remsen Jr., J.V., Rising, J.D., Stotz, D.F. \& Winke. K. (2017). Fifty-eighth supplement to the American Ornithological Society's Check-list of North American Birds. The Auk 134: 751-773.

COSEWIC. (2008). COSEWIC assessment and status report on the Canada Warbler Wilsonia Canadensis in Canada. Committee on the Status of Endangered Wildlife in Canada. Ottawa. vi +35 pp. (www.sararegistry. gc.ca/status/status_e.cfm).

COSEWIC.(2012). COSEWIC assessment and status report on the Eastern Wood-pewee Contopus virens in Canada. Committee on the Status of Endangered Wildlife in Canada. Ottawa. $x+39$ pp. (www.registrelepsararegistry.gc.ca/default_e.cfm).

Cunningham, R.B., \& Lindenmayer, D.B. (2005). Modeling count data of rare species: some statistical tests. Ecology 86(5): 1135-1142.

Davis, D. \& Browne, S. (1996). Natural History of Nova Scotia. 2 Vol. Nimbus Publishing and Nova Scotia Museum, Halifax, NS.

Fagan, W. F., Unmack, P.J., Burgess, C., \& Minckley, W.L. (2002). Rarity, fragmentation, and extinction risk in desert fishes. Ecology 83: 3250-3256.

Freedman, B., \& Johnson, J. (1999). Selected studies of forestry and bird communities in Nova Scotia and New Brunswick. Society of Canadian Ornithologists Special Publication 1: 65-72.

Gaston, K.J. (1994). What us rarity? Population and Community Biology 13: 1-21.

Green, R.H., \& Young, R.C. (1993). Sampling to Detect Rare Species. Ecological Applications 3(2): 351-356.

Hartley, S., \& Kunin, W.E. (2003). Scale dependency of rarity, extinction risk, and conservation priority. Conservation Biology 17: 1559-1570.

Hill,N.M., \& Garbary, D.J.(2011). Habitat may limit herb migration at the northern edge of the Appalachian deciduous forest. Botany 89: 635-645. 
Jennings, M.,Loucks, O., Glenn-Lewin, D., Peet, R., Faber-Langendoen, D., Grossman, D., Damman, A., Barbour, M., Pfister, R., Walker, M., Talbot, S., Walker, J., Hartshorn, G., Waggoner, G., Abrams, M., Hill, A., Roberts, D., \& Tart, D. (2004). Standards for associations and alliances of the U.S. national vegetation classification. Ecological Society of America, Washington. 100 pages.

MacArthur, R.H., \& Wilson, E.O. (1967). The Theory of Island Biogeography. Princeton University Press, Princeton, NJ.

MacKenzie, D.I., Nichols, J.D., Sutton, N., Kawanishi, K., \& Bailey, L.L. (2005). Improving inferences in population studies of rare species that are detected imperfectly. Ecology 86(5): 1101-1113.

Meffe, G.K., \& Carroll, R.C. (1997). Principles of Conservation Biology $2^{\text {nd }}$ Edition. Sinauer Associates, Sunderland, MA.

Neily, P., Basquill, S., Quigley, E., Stewart, B., \& Keys, K. (2011). Forest Ecosystem Classification for Nova Scotia Part I: Vegetation Types (2010). Nova Scotia Department of Natural Resources, Halifax, NS.

Nichols, J. D., Hines, J.E., Sauer, J.R., Fallon, F.W., Fallon, J.E., \& Heglund, P.J. (2000). A double-observer approach for estimating detection probability and abundance from point counts. Auk 117: 393-408.

Nikishina, T.V., Popova, E.V., Vakhrameeva, M.G., Varlygina, T.I, Kolomeitseva, G.L., Burov, A.V., Popovich, E.A., Shirokov, A.I., Shumilov, V.Y., \& Popov, A.S. (2007). Cryopreservation of seeds and protocorms of rare temperate orchids. Russian Journal of Plant Physiology 54(1): 121-127.

Nova Scotia Department of Environment. (2018). Parks and Protected Areas Interactive Map. Province of Nova Scotia. https://www.novascotia. ca/parksandprotectedareas/plan/interactive-map/ [accessed $28 \mathrm{March}$ 2018].

Nova Scotia Department of Natural Resources. (2017). State of Forest Report (2016). Nova Scotia Department of Natural Resources, Halifax, NS.

Oberndorfer, E.C., \& Lundholm, J.T. ( 2009). Species richness, abundance, rarity, and environmental gradients in coastal-barren vegetation. Biodiversity Conservation 18: 1523-1553.

Sherry, T.W., \& Holmes, R.T. (1985). Chapter 9. Dispersion patterns and habitat responses of birds in northern hardwoods forests. In: Cody, M.L. (ed.), Habitat Selection in Birds. Academic Press, Orlando, pp. 283-306.

Stehman, S.V., \& Salzer, D.W. (2000). Estimating density from surveys employing unequal-area belt transects. Wetlands: 20(3): 512-519.

Taylor, B.R., \& Tam, J.C. (2012). Local distribution of the rare plant Triosteum aurantiacum subsp.aurantiacum in northeastern Nova Scotia, Canada. Rhodora 114: 366-382

Thompson, S. K. (1992). Sampling. John Wiley, New York, NY.

Zar, J.H. (1996). Biostatistical Analysis. Prentice Hall Publishers, Upper Saddle River, NJ. 